\title{
Ocular Albinism Type 1
}

National Cancer Institute

\section{Source}

National Cancer Institute. Ocular Albinism Type 1. NCI Thesaurus. Code C118785.

An X-linked inherited disorder caused by mutations in the GPR143 gene. It is characterized by reduced visual acuity and reduced stereoscopic vision. Other abnormalities include nystagmus, strabismus, and photophobia. 